\title{
“SLAVIC TALES” BY Z. A. VOLKONSKAYA
}

\section{Vysotsky A. A.}

\section{INTRODUCTION}

Princess Z. A. Volkonskaya (1789-1862) wrote a number of poetic and prosaic works in French, Italian and Russian, "There is considerable literature about her, and her image is quite well known to readers,” wrote M. Azadovsky, "however for the most part, we are dealing with panegyric literature, in which the ideal image of the writer erases the true essence of her personality and activity" . These lines, written eighty years ago, are relevant today. Until now, the work of Z. Volkonskaya is not among the priority areas of research interests. In that “conciderable literature” mentioned by M. Azadovsky, Volkonskaya’s literary heritage was illuminated fluently without sufficient analysis. Obviously, the prevailing stereotype played a significant role in this case: Z. A. Volkonskaya first of all, is the owner of a bright stage and singing talent, the author of music, the mistress of the music and literature salon, the gathering place of "all the wonderful and selected personalities of modern society"2.

At one time, V. G. Belinsky spoke of Z. Volkonskaya as of one of the most talented writers of the Pushkin era3 which is the time of the formation of Russian historical prose. With her works, the princess took a direct part in this process. S. G. Volkonsky explained the close attention of the "sophisticated representative of young romanticism" to the past by the influence of SlavicGothic patriotism, which arose "under the influence of Karamzin's attitude to Russian history, of that didactism, which penetrates his exposition".

\section{1. "Slavic picture of the $5^{\text {th }}$ century": a romantic plot in a chronicle frame}

In the novel "Tableau Slave du V-me siècle" ("Slavic picture of the $5^{\text {th }}$ century") Volkonskaya refers to the era when the Slavs, according to N. M. Karamzin, go to the "theater of history" 5 . "The primitive state of the Russian Slavs presents so little color for a poetic or prose picture that until now

${ }^{1}$ Азадовский М. Из материалов «Строгановской академии». Неопубликованные произведения Ксавье де Местра и Зинаиды Волконской. Литературное наследство. М.: Изд-во АН СССР, 1939. Т. 33-34. С. 202.

${ }^{2}$ Вяземский П. А. Мицкевич о Пушкине. Вяземский П. А. Полн. собр. соч. СПб., 1882. T. VII. C. 329.

${ }^{3}$ Белинский В. Г. Рецензия. Белинский В. Г. Полн. собр. соч. М.: Изд-во АН СССР, 1955. T. VII. С. 654. Рец. на кн.: Р-ва 3. Сочинения. - СПб., 1843.

${ }^{4}$ Архив декабриста С. Г. Волконского. Пг., 1918. Т. І. Ч. І. С. XXXVIII.

${ }^{5}$ Карамзин Н. М. История Государства Российского. СПб., 1818. Т. І. С. 18. 
almost all the experiments of poets and prose writers in this area have been unsuccessful," wrote the Moscow Telegraph magazine about this period. $-<\ldots>$ Do you want to extract distinctive features, do you want to show us the Slavs where are the materials? There is none of them!" 6 .

Having begun work on the story at the end of 1822, Z. A. Volkonskaya studied Russian and Scandinavian archeology and history under the guidance of the scientist A. Merian during 2 years ${ }^{7}$. "Wanting to show some curious details about the ancient Slavs," wrote the princess, "I tried to combine in a simple and fairly new way everything that came to us about the tribes living along the banks of the Dnieper, their occupations, customs, characters and worship" ${ }^{\text {. The }}$ works of A. L. Shletser, N. M. Karamzin, M. D. Chulkov were the sources of information for Volkonskaya.

In 1824, the novel "Tableau Slave" was anonymously published in Paris and provoked a series of positive reviews. In Russia, the work of Z. Volkonskaya was translated into Russian by P. I. Shalikov and published on the pages of the "Ladies' Journal" in $1825^{9}$. The appearance of the Russian text served as the reason for the polemic between the "Ladies' Magazine" on the one hand and the "Northern Bee" and the "Son of the Fatherland" on the other. Reviewers of the "Northern Bee" and "Son of the Fatherland" criticized the historical inaccuracies of the story, language and style features of the original and translation ${ }^{10}$. The "Moscow Telegraph" defined its attitude towards the Slavic Picture as follows: "the author collects here not only the features that remained in our chronicles and traditions, but everything that the Byzantines and Western Europeans wrote about the Slavs in general, even much that is invented about them"11. The last circumstance, according to the critic, destroyed the historical reliability of the work.

The storyline is based on a chronicle message about the differences in the lifestyle of the Polans and Drevlians. "It seemed to me," Volkonskaya explained her plan, "that I will add to the amusement of the picture, presenting the opposite of morals, concepts of faith and feeling of a person beginning to enjoy the blessings of education, already knowing the works, cultivating the ground, the laws of honor and decency, with life and gross concepts of a creature in a wild state - the deplorable consequence of prolonged humiliation living as a plant or beast, and in which the innate virtues and the immortal soul

${ }^{6}$ Tableau Slave. Славянская картина. Рецензия. Московский телеграф. 1826. Ч. Х. Отд. I. С. 83. Рец. на кн.: Волконская 3. А. Славянская картина V века. М., 1826.

${ }^{7}$ Белозерская Н. А. Княгиня Зинаида Александровна Волконская. Исторический вестник. 1897. № 3. С. 951.

${ }^{8}$ Цит. по: Tableau Slave. Славянская картина. Рецензия. С. 83.

${ }^{9}$ Волконская 3. А. Славянская картина пятого века. Дамский журнал. 1825. Ч. IX. C. 1-32, 43-60, 85-102, 129-146.

10 Белозерская Н. А. Княгиня Зинаида Александровна Волконская. С. 961.

11 Tableau Slave. Славянская картина. Рецензия. С. 84. 
seem to be closed by a rough bark, second only to time or powerful actions of genius educator" ${ }^{\prime 2}$.

Creating "ancient Slavic" flavor, Z. A. Volkonskaya alternates episodes from the life of her heroes with historical and ethnographic insets. Such an approach, according to the author, makes it possible to create a holistic, pretending to authenticity "picture" of the life of ancestors. Ignoring the chronological correlation of events in the sources, Z. Volkonskaya creates pseudo-historical descriptions of rites and celebrations through contamination, which caused controversy among contemporaries. However, it would be unfair to blame the writer for complete incompetence. Images of the morals of the Slavs contain some real features, reflected in the sources.

The destroyer of the cultural confrontation between civilized Polans and savages-Drevlians is Ladovid - the "anachronism" hero, transferred by the will of the writer from her century into the $5^{\text {th }}$ century. Volkonskaya depicts her hero as a young man disappointed in the surrounding world with a "thoughtful gaze" and a "slender stature," expressing himself with an exalted syllable. Fell in love with the "child of nature", the Drevlian Miliada, in which he saw the embodiment of freedom, the "enlightened" Ladovid swears to awaken the "pity and love" in her heart. The assimilation of the Miliada in the Polan environment is facilitated by the birth of children. Parental feelings appear in the story as the ennobling power that contributes to the moral exaltation of a person. The indomitable Miliada rejected by the tribesmen turns into an ordinary, but living according to "civilized" laws, Polan woman. Like the entire composition, its finale is didactic in color. In a prophetic dream, Miliada sees the great fate of her son Kiy and the triumph of the Christian faith on the banks of the Dnieper. The first steps to a true faith have already been made by the Polans: unlike the Drevlians, they treat their gods with remarkable reverence.

On October 16, 1825 Z. A. Volkonskaya was elected an honorary member of the Society of History and Antiquities of Russia at Moscow University. Announcing the chairman of the Society A. A. Pisarev about getting a diploma, the princess wrote: "I have never been indifferent to everything that can contribute to the glory of our Fatherland, which marks reverence for its venerable antiquity, which indicates zeal for its enlightenment. <...> the attention paid by the members of your Society to my tendency toward archaeological research inspires me with a new zeal for useful activities in the field that you intended for your noble exercises" ${ }^{13}$.

12 Цит. по: Tableau Slave. Славянская картина. Рецензия. С. 83-84.

${ }^{13}$ Волконская 3. А. Письмо А. А. Писареву от 10 ноября 1825 г. Труды и летописи Общества истории и древностей российских. 1827. Ч. ІІІ. Кн. 2. С. 160. 


\section{2. "The Legend of Olga": Varangian "accent" of the biography of the princess}

In 1836, the "Moscow Observer", in parts VIII and IX, published fragments of Z. Volkonskaya's new work, “The Legend of Olga”. In an article accompanying the publication, the author of which, most likely, was S. P. Shevyrev, Volkonskaya's creative plan was reported: "The Legend of Olga” will embrace the full picture of Russia of the $10^{\text {th }}$ century, the unity of which will be made up by Olga's life and character, developed from Igor's first love for her until her death. The entire composition will be divided into three parts; the first embraces the complete picture of the mixing of Varangian customs with Slavic and Finnish, first in the north of Russia, then in the south, and among them the gradual development of solid and concentrated character of Olga, who understood the genius of Oleg, was loved by him and didn't find in Igor what she wanted to find in her spouse with her soul and mind. In the second part, her character develops already in action, in the management of Russia, following the example of Oleg: here she is avenging and strict. But Christianity already gradually begins to influence her. The third part takes place in Byzantium, where Olga will appear in the midst of a luxurious and magnificent court, in the kind of Georgian queens who come to them. Piety to superstition, the exact fulfillment of all rites, generosity and mercy for the poor will constitute her character traits in old age" 14 .

Z. A. Volkonskaya conceived to create a work revealing the formation of a separate character against the background of the eventful history of Russia of the first Rurikids. The family traditions were among the reasons that prompted Z. Volkonskaya (nee Princess Beloselskaya-Belozerskaya) to turn to a distant epoch. As A. N. Muravyov wrote, "Rurik's blood flowed in her veins, and the Belozersky clan was especially reverent to all the great enlightener of Russia"15. Life circumstances didn't allow Volkonskaya to finish the novel. The "Works", published in Russian abroad after the death of the princess, included seven chapter songs ${ }^{16}$.

The text of "The Legend of Olga" was created in French and Russian. Touching upon the problem of dating the Russian text, M. A. Harris notes that the exact chronological framework "is difficult to determine, in all likelihood it was written during the Moscow life of Princess Zinaida”17, that is, in 1824 1829. M.A. Harris draws his conclusion based on the testimonies of the Princess' son A. N. Volkonsky, who wrote that in Moscow Z. A. Volkonskaya "studied everything related to the history of ancient Russia: songs, customs,

${ }^{14}$ Отрывок из «Сказания об Ольге». Московский наблюдатель. 1836. Ч. VIII. С. 286-287.

${ }_{15}$ Муравьев А. Н. Знакомство с русскими поэтами. К., 1871. С. 11.

${ }_{16}$ Волконская 3. А. Сказание об Ольге. Волконская 3. А. Сочинения. Париж- Карлсруэ, 1865. C. $37-150$.

17 Гаррис М. А. Зинаида Волконская и ее время. М., 1916. С. 56-57. 
superstition, ancient legends ... <..> She has already begun her novel, "Olga", in French; she decided to write it in Russian. <...> "Olga" remained unfinished" 18 .

“The Legend...” was to cover the life of Princess Olga from 904 to 969. The year 904 marks the fact of Igor's marriage to Olga, and the 969 - the death of the princess ${ }^{19}$. The printed text of the essay ends with a description of events unfolding between 912 (Oleg's death ${ }^{20}$ ) and 941 years (Igor's campaign on Constantinople ${ }^{21}$ ). However, the event information plan is not limited to the specified framework. The heroes of the composition took part in the events of the $9^{\text {th }}$ century, reproduced by them in monologues-memoirs. In general, the plot-compositional features of "The Legend of Olga" are determined by the chronological chronology.

Chronicle reminiscences in the work of Z. Volkonskaya can be found in large numbers: visits to the Slavic lands by the Apostle Andrei, the legend of Varangian tribute, the campaigns of Askold and Dir to Byzantium and their death, the comet during the reign of Oleg, in "The Legend...” there are chronicle characters and so on. The author of "The Legend of Olga" repeatedly uses the annalistic phraseology as well, taking into account the context of its use in the source. “Ходит по сю пору по Олеге”22, “мать русских городов" 23 , “засияла на небе невидимая дотоле звезда" 24 , - these and other verbal constructions in both the annals and "The Legend..." are found in connection with the same events and characters. It should also be noted that some features of the author's style have corresponding analogies in the annals (“Да отсечется язык, который промолвил совет ядовитый! Да будешь ты, каган, везде осенен радостию и златом, и одр твой да устелется любовию дев славянских!”25 and so on).

Believing that modern folk customs are nothing more than the remnants of paganism, Volkonskaya uses ethnographic material to reconstruct the beliefs and rites of her ancestors. For her, as for many contemporaries who wrote about the past, the household features of the national structure did not undergo significant changes for many centuries. Here, for example, is a description of a winter evening in a medieval settlement: “Там, на посиделках, молодцы затевали игры, молодицы пряли, пели <...>. Старухи садились у очага; одни гадали, глядя на зажженную березовую лучину; другие... толковали

${ }^{18}$ Гаррис М. А. Зинаида Волконская и ее время. М., 1916. С. 57.

${ }^{19}$ Патриаршая, или Никоновская летопись. Полн. собр. рус. летописей. М.: Наука, 1965.

T. 9-10. XXIII, C. 18, 34-35.

20 Патриаршая, или Никоновская летопись, С. 21-22.

${ }^{21}$ Повесть временных лет. М.-Л.: Изд-во АН СССР, 1950. Ч. 1. С. 33.

${ }^{22}$ Волконская 3. А. Сказание об Ольге. С. 70.

23 Там же. С. 74.

24 Там же. С. 32

25 Там же. С. 97. 
сны, рассказывали про добрые и злые встречи, про оборотней и про юных рыбаков, пропавших в озере и унесенных на дно Водяным дедом. Девицы и парни, любовь на уме, собирали в деревянное блюдо ожерелья и кольца, вынимали под песни, и песни гласили им то свадьбу, то дальний путь, то богатство, то скорую смерть" 26.

The works of A. L. Shletser, N. M. Karamzin, M. P. Pogodin helped to build Volkonskaya's own historical concept. The period when the writer worked on "The Legend..." was a time of debate over the merits and demerits of the conceptual provisions of Karamzin's “History of the Russian State”. The era depicted in "The Legend of Olga" was the focus of the debate. The problem of the emergence of the Old Russian state, according to V.P. Kozlov, "had a long historiographic tradition. Already in the $18^{\text {th }}$ century, its decision focused on the discussion of three issues: on the level of development of Slavic tribes before the calling of the Varangian princes and, therefore, on the role of internal causes in the formation of the Old Russian nationality and statehood; on the ethnicity of the Varangian princes and the role of the "Varangian" element in the development of the Old Russian state; on the political organization of the Slavic tribes of the "Before Rurik" period of their history, the nature of the rule of the first Rurikids and, therefore, the role of the monarchist element in the development of Ancient Russia" 27 . The opinions expressed on these topical issues in the first third of the $19^{\text {th }}$ century were of a very different nature - from the Pro-Varangian to the Anti-Norman.

For Volkonskaya Russia of the first princes is a conglomerate of Finnish, Lithuanian and Slavic tribes, living according to their own laws, but not isolated from each other at all. Therefore, it is not surprising that the people of Kiev in "The Legend...” worship Siva and Nemiz, and on the shores of Peipsi Lake they honor Odin, Perun and Bel-God. This historical situation also explains the mixture of funeral rites and customs.

862-941 years in the perception of Volkonskaya - the era of the Normans. The Scandinavians who came to Russia act as peculiar demiurges. At one time, Schletser argued that the half-wild inhabitants of the Russian North did not have "a single city so-called" 28 , before the Varangians arrived, and "lived under a democratic, or better, under no rule" 29 . In "The Legend of Olga", the state of the tribes inhabiting the occupied lands is characterized in a similar way. The Varangian Truvor, for example, who arrived in the city of Krivichi Izborsk, finds it a “crow’s nest”. Truvor “научил дикарей строить жилья покойные, крыть крышами капища кумиров, обводить плетнями сады и домы” ${ }^{30}$. At

${ }^{26}$ Волконская 3. А. Сказание об Ольге. С. 61-62.

${ }^{27}$ Козлов В. П. «История государства Российского» Н. М. Карамзина в оценках современников. М.: Наука, 1989. С. 178.

${ }^{28}$ Шлецер А. Л. Нестор. СПб., 1809. Ч. І. С. 52.

${ }^{29}$ Шлецер А. Л. Нестор. С. 51.

${ }^{30}$ Волконская 3. А. Сказание об Ольге. С. 53. 
the same time, Novgorod, founded by Rurik, flourished. The remaining tribes that live on the periphery remain wild even under the successors of Rurik.

Z. A. Volkonskaya did not show in detail the arrival of Rurik, Sineus, and Truvor: sources known to her too briefly. The Varangian brothers are depicted in "The Legend..." schematically: «Рюрик был разумен, суров и храбр; Синеус искусен на играх, быстро летал на коньках, ловко боролся; но Трувор... лучше его стрелял из лука» ${ }^{31}$. Aliens make up the highest power among the Slavs and profess native laws. They strongly emphasize their exclusivity: «...гордые варяги обидными словами раздражают старцев киевских... Жрецы, колдуны, колдуньи, всякий в свою очередь становится предметом дерзкой насмешки варягов» ${ }^{32}$. «Надо быть норманном, чтобы пройти Океан во всю длину его» ${ }^{33}$, - one of the northerners exclaims, neglecting the geographical ignorance of Kiev merchants.

Z. A. Volkonskaya depicts the life, customs, and natural conditions of life of the Scandinavians as they are presented in the works of P. A. Malle and O. Dalin, known to the reader of that time. The Scandinavians in "The Legend...” are, first of all, the Vikings, participants in the robber sea raids. Normans are harsh unpretentious warriors who "умирая, смеются" ${ }^{34}$. In battle the Scandinavians are seized by "ярое бешенство" 35 . They despise peace and the slightest manifestation of feelings, drink wine from the skulls of enemies and spend their lives in battles led by the "морские короли" ". "Веселье, любовь, злато, пьянство" 37 - this is the meaning of the life of a northerner. Expressive "Viking" details are contained in the descriptions of the campaigns of the "sea king" Hastings and Prince of Kiev Igor.

The problem of the aliens' ethnicity in Rus remained unresolved in the 1920s. Schletser argued that the chronicle Varangians "were Normans, and it was Swedish, that then, as now the Swedes were called Russes in some lands" ${ }^{38}$. Karamzin, without denying the Scandinavian origin of the chronicle brothers $^{39}$, refrained from specifying. In 1825, M.P. Pogodin defended his master's thesis "On the Origin of Rus", in which, rejecting the belonging of the Varangians-Rus to Swedes, Prussians, Finns, Khazars, Goths of the Black Sea and Frieslanders, he came to the conclusion: "Varangians-Rus was constituted

${ }^{31}$ Волконская 3. А. Сказание об Ольге. С. 52.

32 Там же. С. 77.

33 Там же. С. 46

34 Там же. С. 42. Sее См. также: Малле П. А. Введение в историю датскую, в котором рассуждается о вере, законах, нравах и обыкновениях древних датчан. СПб., 1785. Ч. 1. C. 156 .

${ }^{35}$ Там же. С. 45

${ }^{36}$ Там же. С. 41. См. также: Далин О. История Шведского государства. СПб., 1805. Ч. I. Кн. 1 - 2. С. 355, 110.

37 Там же. C. 50.

${ }^{38}$ Шлецер А. Л. Нестор. С. 344.

39 Карамзин Н. М. История Государства Российского. С. 48. 
by a Norman tribe living in present-day Sweden” ${ }^{40}$. Volkonskaya also does not give a clear answer to the question in "The Legend..." However, Truvor and his brothers, according to the writer, lived in Sweden, in Uppsala before their "calling" 41 .

For the author of "The Legend of Olga", the vocation of Rurik, Sineus, and Truvor is the primary cause of statehood. Rurik and Truvor are opposed as two types of rulers. Rurik founded the "new town", which became a rich trade center, Truvor could not "civilize" Izborsk until the end and was left by the warriors who left for Novgorod to Rurik. The imminent death of Truvor, who died of longing, Volkonskaya, firstly, emphasizes her agreement with the annals, which reports death two years after calling, in $865^{42}$; secondly, she affirms the idea of Novgorod land as the cradle of the Russian state (according to Schletser, Russia was originally called the Novgorod land ${ }^{43}$ ).

The plot development of "The Legend of Olga" is determined by the opposition "northerners - the local population". If the Truvor's warriors were forced to defend themselves against wild tribes constantly, then under Oleg and Igor the confrontation acquired a new quality: clashing of customs and traditions. The Vikings of the time of Igor are not like those who came with Rurik. They are no longer bearers of characteristic ethnic qualities in a "pure" form. The Normans in "The Legend of Olga" are split into two camps. Veterans of Rurik and Truvor want to adhere to their customs on a foreign land. To the young Varangians (including the favorite Igor Sveneld), brought up among the Slavs, "the customs and gods of the Scandinavian were alien ${ }^{44, "}$ A similar characteristic can be seen in Karamzin's work, who noted: “...the Vikings dominated Kiev for fifty years; Igorev's peers, like him born between the Slavs, no doubt spoke their language better than Scandinavian" ${ }^{45}$. Following its sources, Volkonskaya, recognizing the Norman "first push", does not deny the participation of the Slavs in the emergence of statehood. The development of the Normans in the local environment began immediately after their arrival. But the main role in this process was played by Prince Oleg.

A. L. Schletser wrote about Oleg as follows: "How long would another power, even composed of the people who had barely come out of wildness and surrounded by equally rude people, have remained in their primitive smallness and rudeness if Oleg had not appeared" ${ }^{46}$. His idea was continued by N. M. Karamzin: "By joining the best, richest countries of present-day Russia to

${ }^{40}$ Погодин М. П. О происхождении Руси. М., 1825. С. 177.

${ }^{41}$ Волконская 3. А. Сказание об Ольге. С. 52.

42 Патриаршая, или Никоновская летопись, С. 9.

43 Шлецер А. Л. Нестор. С. 344.

44 Волконская 3. А. Сказание об Ольге. С. 111.

45 Карамзин Н. М. История Государства Российского. С. 140.

${ }^{46}$ Шлецер А. Л. Нестор. Русские летописи на древле-славенском языке. СПб., 1816. Ч. 2. C. $146-147$. 
this power, this prince was the true founder of its greatness" ${ }^{47}$. The significance of Oleg's activities was also noted by N. A. Polevoy, who pointed out: "His memory was precious to the Russians, who saw him as a true prince, courageous, brave, and enterprising" 48 . Such enthusiastic reviews are based on reports from annalistic sources about the scope of Oleg's efforts to strengthen Russia.

The characteristic of Oleg by Z. A. Volkonskaya is no exception. Exclusivity is emphasized by his "prophetic" abilities and external qualities (his anger is like thunder, his eyes sparkle like lightning ${ }^{49}$ ). Oleg's affairs in "The Legend of Olga" are consonant with the historiographer's words that "only the hero's strong hand establishes great empires and serves as a reliable support for their dangerous news" ${ }^{50}$.

Oleg continues the work of his father Prince Igor Rurik, who believed that the prosperity of the state is possible only if the aliens respect the local traditions. "Тебе ведомо", the Varangian carrier tells Igor, - что наши дети должны разуметь веру славянскую. Так велел отец твой и так велит Олег”51. Tо emphasize the propinquity of Prince Oleg to the Slavic cultural tradition, the writer stylizes her hero's speech in a folklore manner. Norman anger pacifies the Slavic song "bylina" (incidentally, it should be noted that in "The Legend ..." you can often find examples of the use of epic-fairy-tale vocabulary and phraseology («яства лакомые», «удалой молодец», «конь ретивый», «темный лес», «буйные головы», «красное солнышко», «мурава», «кручиниться» еtс.). «А и того не забыть, братцы, - the people of Kiev say about Oleg, - что ....князем... нашим зовется: славянский князь» ${ }^{52}$.

Oleg supports his authority on the Slavic lands, in particular, and that promotes the development of trade: «После княжеских бесед часто отправлялся обоз с киевскими выбранными купцами и тиунами, и с провожатым варягом; примечали, что берет всегда дорогу южной Хозарии и что в то же время посылались в Новгород, в Смоленск, к древлянам и в Червленные области бояре иль тиуны» ${ }^{53}$.

The image of Oleg embodied the author's concept of the monarchy. Oleg appears in the "Legend ..." as a wise and visionary sovereign. He sees the pledge of state power in the peaceful coexistence of aliens with natives, which is possible in case of reverence for local traditions. Having commanded his tribesmen to respect Slavic customs, Oleg himself adheres to this rule: Igor's wedding was played in Slavic; Normans draw up an agreement with Byzantium in the Slavic language - the language of the majority; the prince is surrounded

${ }^{47}$ Карамзин Н. М. История Государства Российского. С. 143.

48 Полевой Н. История русского народа. М., 1829. Т. 1. С. 133.

49 Волконская 3. А. Сказание об Ольге. С. 88.

${ }^{50}$ Карамзин Н. М. История Государства Российского. С. 143.

51 Волконская 3. А. Сказание об Ольге. С. 57.

52 Там же. С. 79.

53 Там же. С. 81. 
not only by the Vikings, but also by the Slavs; he is buried according to the Scythian-Slavic custom, etc.

The rule of Oleg is a model through the prism of which Z. A. Volkonskaya evaluates the deeds of his successor. One of the characters in "The Legend of Olga" utters words that determine the character of Prince Igor's image throughout the entire work: «Ты не Олег!» ${ }^{54}$ (summing up Igor's reign, N. M. Karamzin concluded: “Igor didn't seem to have and his great properties (Oleg. - A.V.) ${ }^{55}$ ).

Prince Igor in Volkonskaya's composition is represented by a man unsuitable for state affairs. His concerns are feasts and hunting. Igor is afraid of his guardian Oleg and remains submissive to him until the death of the old prince. The writer repeatedly portrays Rurik's son in a friendly environment, where Igor feels rather comfortable. The simplicity between the leader and the warriors was common for the Scandinavians who spoke "with their king, as with their friend or as a son with their father" ${ }^{36}$. But this simplicity allows soldiers to subordinate Igor to their will. Knowing what role the retinue of Igor played in his death, Volkonskaya shows the prince unable to stop the manifestation of discontent from the soldiers.

Igor is reminiscent of Prince Svyatoslav with his passion for military pleasures, at least in such a detail: in the hearth, Igor «жарил под горячей золою отборный кус конины» ${ }^{57}$. Paying attention to the similarities in the habits of father and son, Z. A. Volkonskaya, firstly, perceives this detail as a common feature of the retinue life of that time, and, secondly, tries to justify the "minuses" of the reign of Svyatoslav, whom N. M. Karamzin, for example, did not consider the example of "the great sovereign: he respected the glory of victories more than the state good" $" 58$.

After the death of Oleg, Igor still does not show interest in public affairs, giving his man-at-arms Sveneld the opportunity to dispose of them. Z. Volkonskaya complements the prince's image with characteristic touches: closefisted Igor, who won the warrier, does not favor his princely gift, but forces the merchants to reward the hero ${ }^{59}$; the solution to the question of collecting tribute from the prince depends on the outcome of the dice ${ }^{60}$. Igor is indifferent not only to the Slavic, but also to the Varangian gods.

The qualities that Prince Igor is endowed with in Volkonskaya's work together make up not only the individual characteristics of this character, but also serve as a contrasting background for the image of the main character. The

54 Волконская 3. А. Сказание об Ольге. С. 119.

55 Карамзин Н. М. История Государства Российского. С. 157.

56 Далин О. История Шведского государства. С. 346.

57 Волконская 3. А. Сказание об Ольге. С. 95.

58 Карамзин Н. М. История Государства Российского. С. 194.

59 Волконская 3. А. Сказание об Ольге. С. 119.

60 Там же. C. 127-128. 
idealization of Olga in the work is obvious. This is explained not only by the influence of the historiographical stereotype, but, in all likelihood, by the fact that Volkonskaya described the life of her ancestors (in addition, her husband N. G. Volkonsky - Rurikovich in the $26^{\text {th }}$ generation). Olga is shown as a worthy successor of Oleg's undertakings. The etymological kinship of names pointed to by M. P. Pogodin ${ }^{61}$ takes on a special meaning. Pogodin's opinion about Olga's Varangian origin ${ }^{62}$ determined Olga's ethnicity in Volkonskaya's composition.

As the true daughter of a Varangian, Olga was brave and courageous (for example, O. Dalin wrote about the courage of Scandinavian women ${ }^{63}$ ). She is «в легком суденушке не боится никаких бурь» ${ }^{64}$; in order to return the bridegroom, Olga participates in witchcraft rites and makes sacrifices with her own hand ${ }^{65}$. Olga understands the intricacies of military affairs.

After the death of Oleg, Olga is actually the regent under Igor. She requires the completion of the Slavic funeral rite over the deceased prince and gives wise advice to her husband: «Не слушайся отца (Ольги. - A. B.) и варягов: ты княжишь над славянами: а ведь что сделано Рюриком и Олегом, то все обдумано, все зрело. Можно ль меньшему одолеть большее? Если все славяне соберутся да вздумают обступить вас и выжить, как вы с ними сладите? Ведь вы топчете чужую землю, а не своя земля бежит, что вода под ногами» ${ }^{66}$. Olga sees support of princely power in merchants.

Olga is shown by Z. A. Volkonskaya as a worthy ruler, continuing and developing the experience of Prince Oleg. Oleg «понял ее доблестный нрав и хитрый разум: часто ее звал на совет, когда решал суды и забавлялся иногда уступать прекрасной княгине право прощать виновного или отгадывать запутанное какое дело. Он видел в ней под женскою фатою разум достойного мужа и часто говорил старикам: «Вот вам Олег после меня: она напрядет дела доброго. «Жаль, - говорил он часто отцу молодой княгини, - она поздно родилась для моего супружества, а то бы я Рюриковичу ее не уступил» ${ }^{67}$.

In the image of Volkonskaya, Olga takes a drama hard: Igor was far from the ideal husband and ruler, did not justify her first impressions. Having become a princess, Olga «мучилась бездействием супруга своего и неуважением старцевых (Олега. - A. В.) воинов к нему; она видела, что в нем мало надежного, осуждала много в душе своей; но не смела про то слова

61 Погодин М. П. Нечто о роде великой княгини Ольги. Труды и летописи Общества истории идревностей Российских. 1828. Ч. IV. Кн. 1. С. 136.

62 Погодин М. П. Нечто о роде великой княгини Ольги. С. 137-138.

63 Далин О. История Шведского государства. С. 366 - 368.

${ }^{64}$ Волконская 3. А. Сказание об Ольге. С. 57.

65 Там же. С. 66.

66 Там же. С. 109.

67 Там же. С. 82. 
промолвить, ибо, не имея детей, не находила в себе права с супругом смело изъясняться» ${ }^{68}$. Olga asks Oleg to influence Igor, to involve him in the "princely courts". With her flattery, Olga averts the wrath of the old prince from Igor and his soldiers ${ }^{69}$. The Princess is sorry for her husband, whose name is not chanted in songs. Igor's indifference annoys her, leads to confusion. «Что c ним делать? Тошнехонько, ...часто сердце щемит!», Olga complains ${ }^{70}$. Trying to influence her husband, the princess turns for help to Sveneld, then to the old warrior, her supporter Asmud. The lack of attention to herself from her spouse also gives Olga a lot of disappointments.

Relations between spouses do not bear any kind of "Old Russian" imprint. Volkonskaya describes them as if she herself had to feel the same as the heroine of "The Legend...". The following parallels can be assumed: Oleg - Alexander I, Olga - the writer herself, Igor - N. G. Volkonsky. It is known that there was mutual sympathy between Volkonskaya and the emperor, Alexander I was the ideal of a "knight" for her ${ }^{71}$. About N. G. Volkonsky, who could serve as a prototype of weak-willed Igor, N. G, Volkonsky wrote: «Князь Никита Григорьевич, муж «очаровательницы» Зинаиды, был, по-видимому, человек очень слабовольный, характера вялого. По словам Жозефины, он питал отвращение к движению, вечно полулежал в кресле. Это была воплощенная лень» ${ }^{72}$.

Preparing the reader for the perception of the life of Christian Olga, Volkonskaya replies that Christians appeared under Askold and Dir in Russia. The first Christians were Varangians who went with princes to the "Christian land" and were baptized there. However, Christian teaching was brought to Russia not only by the Varangians, but also by missionaries from Moravia - the disciples of Cyril and Methodius. The process of spreading new faith was difficult. Yesterday's pagans did not want to say goodbye to their gods, rites and customs.

Volkonskaya's assessment of Princess Olga's personality, in addition to traces of the influence of the historiographical tradition, reflects the author's ideas about the ideal and about those or other features of the historical process. Volkonskaya's views on the role of the individual in history fit into the framework of early romance subjectivism. On the whole, faithfully reproducing in her work the logic of the events of reality, Volkonskaya is inclined to explain this logic as a rational or emotional principle of a human character. Nevertheless, "The Legend of Olga" contributed to the development of Russian historical prose, because the reproduction of the most important stages of Russian history contributed to its knowledge and comprehension. The same can be said about the story "Tableau Slave du V-me siècle" ("Slavic picture of the $5^{\text {th }}$ century").

68 Волконская 3. А. Сказание об Ольге. С. 82.

69 Там же. С. 88.

70 Там же. С. 125.

71 Азадовский М. Из материалов «Строгановской академии». С. 203.

72 Архив декабриста С. Г. Волконского. С. XXIV. 


\section{CONCLUSIONS}

Having chosen the pre-state period of East Slavic history as the subject of the description in the "Tableau Slave du V-me siècle" ("Slavic picture of the $5^{\text {th }}$ century”), Z. A. Volkonskaya interprets the annalistic confrontation between the Polans and the Drevlians as a conflict of barbarism and culture. Enlightening ideas influenced the image of the writer of past events. According to Z. Volkonskaya, familiarizing a savage with a civilized way of life is the basis of his moral growth. "A child of nature", in an enlightened environment, is exposed to it and turns into a civilized person. The lack of information about the life of the ancient Slavs, due to the development of science of those times, determined the conditionally historical nature of the descriptions of the "Slavic picture", against which the fictional protagonists Ladovid and Miliada act. At the same time, Volkonskaya proved herself to be an expert on the available historical material.

"The Legend of Olga" was conceived by the writer as a historical and biographical work about the life of the famous princess. A sufficiently high level of historical awareness of Z. A. Volkonskaya was reflected in the sketches from the life of Russia of the first princes. The historical concept of the writer is largely determined by the works of A. L. Shletser and M. P. Pogodin. For the author $862-941$ years in the history of Russia are a period of domination of the Scandinavians, opposed to the Slavs by their national character and traditions.

The author's plan required not only the reconstruction of ancient life and customs, but also the image of persons (Olga, Oleg, Igor) who left this or that trace in the history of the state as carriers of a certain type of human qualities. On the whole, correctly reflecting the sequence of events reflected in the sources, Z. Volkonskaya is inclined to explain it with rational or emotional principles of a human nature. "The Legend..." contributed to the development of Russian historical prose in the first third of the $19^{\text {th }}$ century, because the reproduction of key milestones in Russian history contributed to its knowledge and comprehension.

\section{SUMMARY}

An analysis of the historical prose of Z. A. Volkonskaya (1789-1862), the results of which are presented in the article, allows us to make the assumption that the writer, addressing the theme of early Russia, sought to comprehend the logic of the development of history, comprehend its experience, and develop its own forms artistically-historical storytelling. It is noted that the connection of the plot of "The Legend of Olga" by Z. Volkonskaya with the annalistic chronology is due to the biographical orientation of the work. Volkonskaya was conceived an essay in which the fates of the heroes are shown against the background of events of national historical significance. Attention is drawn to the fact that the author comprehends the key moments of the history of the second half of the $9^{\text {th }}$ - beginning of the $10^{\text {th }}$ centuries associated with the 
artistic being of the annalistic characters of persons. This explains the writer's interest in both the historical and the everyday plan of the plot action (coming from her «Tableau Slave du V-me siècle»). The solution of the question of the conceptual basis of Z. A.Volkonskaya's works makes it possible to assert that her prose ("The Legend of Olga") was influenced by the normanistically colored regulations of the then theories about the initial period of statehood formation among the Eastern Slavs. However, such a position does not prevent the writer from following a certain logic of historical development, portraying A. L. Shletser, who was surprised at his transience, the process of assimilation of the Scandinavian element in the local environment. The features of this process are associated with $\mathrm{Z}$. Volkonskaya, in particular, with the influence of the personal will of the ruler. The educational thesis "opinions rule the world" was embodied in the images of Oleg and Olga. The characterization of Prince Igor reflected the author's thought that the true monarch is the one who can rule, and not the one who is only called. It is possible that the artistic depiction of the relationship between Oleg, Olga and Igor hides the facts from the biography of Z. A. Volkonskaya herself and the people around her.

\section{REFERENCES}

1. Азадовский М. Из материалов «Строгановской академии». Неопубликованные произведения Ксавье де Местра и Зинаиды Волконской. Литературное наследство. М.: Изд-во АН СССР, 1939. Т. 33-34. С. 195-214.

2. Архив декабриста С. Г. Волконского. Пг., 1918. Т. І. Ч. І. XLVIII, 526 c.

3. Белинский В. Г. Рецензия. Белинский В. Г. Полн. собр. соч. М.: Изд-во АН ССCР, 1955. Т. VII. С. 648 - 678. Рец. на кн.: Р-ва 3. Сочинения. - СПб., 1843.

4. Белозерская Н. А. Княгиня Зинаида Александровна Волконская. Исторический вестник. 1897. № 3. С. 939-972.

5. Белозерская Н. А. Княгиня Зинаида Александровна Волконская. Исторический вестник. 1897. № 4. С. 131-64.

6. Волконская 3. А. Письмо А. А. Писареву от 10 ноября 1825 г. Труды и летописи Общества истории и древностей российских. 1827. Ч. III. Кн. 2. С. 160.

7. Волконская 3. А. Сказание об Ольге. Волконская 3. А. Сочинения. Париж- Карлсруэ, 1865. С. 37-150.

8. Волконская 3. А. Славянская картина пятого века. Дамский журнал. 1825. Ч. IX. С. 1-32, 43-60, 85-102, 129-146.

9. Вяземский П. А. Мицкевич о Пушкине. Вяземский П. А. Полн. собр. соч. СПб., 1882. Т. VII. С. 306 - 332.

10. Гаррис М. А. Зинаида Волконская и ее время. М., 1916. 136 с.

11. Далин О. История Шведского государства. СПб., 1805. Ч. І. Кн. 1-2. XXI, 956 c. 
12. Карамзин Н. М. История Государства Российского. СПб., 1818. T. I. XXXVI, 254, 220 c.

13. Козлов В. П. «История государства Российского» Н. М. Карамзина в оценках современников. М.: Наука, 1989. 223 с.

14. Малле П. А. Введение в историю датскую, в котором рассуждается о вере, законах, нравах и обыкновениях древних датчан. СПб., 1785. Ч. 1. $\mathrm{XV}, 320 \mathrm{c}$.

15. Муравьев А. Н. Знакомство с русскими поэтами. К., 1871.35 с.

16. Отрывок из «Сказания об Ольге». Московский наблюдатель. 1836. Ч. VIII. C. 286-287.

17. Патриаршая, или Никоновская летопись. Полн. собр. рус. летописей. М.: Наука, 1965. Т. 9-10. XXIII, 244 с.

18. Повесть временных лет. М.-Л.: Изд-во АН СССР, 1950. Ч. 1. 407 с.

19. Погодин М. П. Нечто о роде великой княгини Ольги. Tpydbl и летописи Общества истории и древностей Российских. 1828. Ч. IV. Кн. 1. С. 130-138.

20. Погодин М. П. О происхождении Руси. М., 1825. 177 с.

21. Полевой Н. История русского народа. М., 1829. T. 1. LXXXII, 368, VII c.

22. Tableau Slave. Славянская картина. Рецензия. Московский телеграф. 1826. Ч. Х. Отд. І. С. 82-85. Рец. на кн.: Волконская 3. А. Славянская картина V века. М., 1826.

23. Файнштейн М. Ш. Писательницы пушкинской поры (историколитературные очерки). Л.: Наука, 1989. 176 с.

24. Шлецер А. Л. Нестор. СПб., 1809. Ч. I. 7, 16, XLI, 475 с.

25. Шлецер А. Л. Нестор. СПб., 1816. Ч. 2. 4, 832 с.

\section{Information about the author:}

Vysotsky A. A.

Candidate of Philological Sciences, Associate Professor at the Department of World Literature and Culture named after professor O. Mishukov

of the Kherson State University 40 rokiv Zhovtnya str., Kherson, 73000, Ukraine 